\title{
REDESAIN MESIN PEMUTAR DAN REVITALISASI MANAJERIAL PENGUSAHA ES KRIM DI MEDAN
}

\author{
Muslim \\ Fakultas Teknik, Universitas Negeri Medan, Medan \\ *Penulis Korespondensi: muslim@unimed.ac.id
}

\begin{abstract}
Abstrak
Pembuatan es krim atau "es puter" yang dilakukan oleh pengusaha kecil selama ini adalah dengan cara memutar tabung sederhana, dengan cara pembuatan seperti ini kurang efisien dan tidak produktif. Manajemen pengelolaan masih konvensional, tidak memiliki ijin usaha, sebagai produk makanan tidak ada ijin dari Balai Pengawasan Obat dan Makanan (BPOM) dan sertifikasi halal dari Majelis Ulama Indonesia (MUI). Tujuan kegiatan Iptek bagi Masyarakat $\left(I_{b} M\right)$ ini adalah membantu mitra dalam menyelesaikan permasalahan yang dihadapinya untuk mengembangkan usaha mitra agar dapat meningkatkan efisiensi produksi, mandiri secara eknomi baik dalam aspek permodalan maupun ekonomi. Metode yang digunakan untuk mencapai tujuan kegitan IbM adalah metode pendampingan perbaikan proses produksi, penyuluhan, pelatihan produksi, pelatihan manajemen usaha. Hasil kegiatan IbM ini adalah sebagai berikut: (1) mesin pemutar es krim memiliki efisiensi dua kali lipat dibanding sebelumnya, (2) mudah mengoperasika (3) terbuat dari bahan stainless sehingga lebih higienis (4) mitra usaha memiliki buku laporan keuangan (buku kas, neraca rugi laba, perhitungan keuntungan) (5) mitra usaha dapat membuat proposal kredit usaha untuk mengembangkan usahanya dan (6) mitra usaha mengurus perijinan usaha dan membuat merek serta setifikasi produk dari BPOM dan MUI.
\end{abstract}

Kata Kunci: Es Krim Putar, Redesain Mesin, Pengembangan Usaha

\begin{abstract}
Making ice cream or "ice puter" which is done by small entrepreneurs so far is by turning simple tubes, by way of making like this less efficient and not productive. The production management is still conventional, does not have a business license, as a food product there is no permit from BOM Hall and halal lebel from MUI. The purpose of science and technology activities for the Society (IbM) is to help partners in solving problems faced to develop business partners in order to improve production efficiency, independently eknomi both in capital and economic aspectsThe methods used to achieve IbM's aims of interest are the method of assisting the improvement of production processes, counseling, production training, business management training. The results of IbM's activities are as follows: (1) the ice-cream machine has boosted a more efficient production (2) more effective production time (3) made of stenles so that higihenes (4) the business partner has a book of financial statements (cash book, (5) business partners can prepare a loan proposal to expand their business from financial services and (6) business partners take care of business licenses and make brands and furniture from BPOM and MUI..
\end{abstract}

Keywords: Scoop Ice Cream, Redesigning Ice Cream Maker, Business Development

\section{PENDAHULUAN}

Es krim dikenal sejak zaman Romawi, yaitu pada 400 tahun Sebelum Masehi. Produksi es krim secara komersial mulai dilakukan pada abad ke-18, menyusul ditemukannya mesin freezer pada tahun 1846. Pabrik es krim pertama dibangun di Baltimore, Amerika Serikat, pada tahun 1851. Es krim dapat dikatakan sebagai jenis hidangan paling populer di dunia. Pada tahun 2003, produksi es krim dunia mencapai lebih dari satu miliar liter dan dikonsumsi oleh miliaran konsumen per tahun. Menurut Standar
Nasional Indonesia, es krim adalah sejenis makanan semi padat yang dibuat dengan cara pembekuan tepung es krim atau campuran susu, lemak hewani maupun nabati, gula, dan dengan atau tanpa bahan makanan lain yang diizinkan. Di pasaran, es krim digolongkan atas kategori economy, good average dan deluxe.

Struktur dan kandungan es krim tidak lain berupa busa (gas yang terdispersi dalam cairan) yang diawetkan dengan pendinginan. Walaupun es krim tampak sebagai wujud yang padu, bila dilihat dengan 
mikroskop akan tampak ada empat komponen penyusun, yaitu padatan globula lemak susu, udara (yang ukurannya tidak lebih besar dari $0,1 \mathrm{~mm}$ ), kristal-kristal kecil es, dan air yang melarutkan gula, garam, dan protein susu. Berbagai standar produk makanan di dunia membolehkan penggelembungan campuran es krim dengan udara sampai volumenya menjadi dua kalinya (disebut dengan maksimum 100 persen overrun). Es krim dengan kandungan udara lebih banyak akan terasa lebih cair dan lebih hangat sehingga tidak enak dimakan. Bila kandungan lemak susu terlalu rendah, akan membuat es lebih besar dan teksturnya lebih kasar serta terasa lebih dingin. Emulsifier dan stabilisator dapat menutupi sifat-sifat buruk yang diakibatkan kurangnya lemak susu dan dapat memberi rasa lengket.

Es krim merupakan jenis makanan semi padat yang disukai oleh segala lapisan masyarakat, baik tua, muda, apalagi anak-anak. Dalam setiap acara pesta, misalnya pesta pernikahan, khitanan, ulang tahun, dan acara lainnya, menu es krim hampir selalu ada. Hidangan makanan/minuman tersebut umumnya dilayani oleh usaha catering yang banyak terdapat di kota, bahkan di desa. Selain dibuat oleh usaha catering, es krim juga banyak dibuat oleh home industri atau industri kecil yang khusus memproduksi es krim untuk dijual langsung ke konsumen dengan cara menetap maupun dijajakan keliling oleh para penjaja/ pedagang.

Usaha pembuatan es krim putar yang terletak di Jalan Perjuangan, Keluaran Sidorejo, Kecamatan Medan Tembung, Kota Medan yang hanya berjarak sekitar $2 \mathrm{~km}$ dari kampus Unimed, bermula dari hasil pengalaman Bapak Tukidi dan Bapak Wiji yang di peroleh dari buruh pembuatan es krim dari juragan saat di kampung halaman di Solo. Berkat pengalamannya sekitar 15 tahun yang lalu akhirnya membuat usaha es krim putar sederhana yang hanya melayani untuk jualan keluarga $2-3$ orang penjual keliling. Namun saat ini sudah berkembang terus untuk memenuhi kebutuhan es krim di pingiran kota Medan yang terus meningkat.

Kapasitas produksi es krim Pak Tukidi mencapai 14 tabung per hari atau sekitar $280 \mathrm{~kg}$ per hari, dan Pak Wiji mencapai 12 tabung atau sekitar $240 \mathrm{~kg}$. Para penjual yang terlibat penjualan mencapai 40 orang. Lokasi pembuatan es krim putar ini sangat strategis selain di pingir kota yakni perbatasan Deli Serdang juga terletak di lingkungan pendidikan dan daerah pertumbuhan sehingga memiliki prospek usaha yang sangat tinggi. Dengakan kapasitas produksi tersebut masih terus kekurangan apalagi kalau sudah ada pesanan dari kegiatan pesta atau hajatan kebutuhannya bisa dua kali lipat.

Produksi es krim putar ini selaian melayani penjual keliling juga menerima pesanan pribadi dan pesta/hajatan. Es krim putar ini meiliki aneka rasa ada rasa durian, stroberi, coklat, rasa nangka dll, dengan harga relatif murah sehingga sangat di gemari masyarakat.
Berdasarkan survei yang dilakukan tim pelaksana, ternyata hampir semua industri kecil atau usaha catering yang memproduksi es krim tersebut, dalam membuat es krim masih dengan cara konvensional. Prinsip pembuatannya adalah: tabung atau termos yang berisi adonan bahan-bahan es krim (gula, santan, susu, hongkwe, garam, dll) dimasukkan dalam kotak/wadah yang berisi campuran es batu dan garam, kemudian diputar dengan tangan selama kurang lebih 1,5 hingga 2 jam. Oleh karena itu es krim buatan home industri sering disebut "es puter", karena cara membuatnya dengan cara diputar.

Dengan cara pembuatan seperti ini, sangat tidak efisien, karena satu orang harus memutar satu tabung hingga menjadi es krim. Padahal es krim umumnya dijajakan atau dijual dalam waktu serentak, sehingga dibutuhkan banyak tenaga kerja yang bertugas memutar tabung tersebut jika ingin menghasilkan banyak es krim. Selain itu, dengan cara manual aspek kebersihan atau higienitas makanan kurang terjamin, serta pekerja akan cepat lelah/capai.

Hal lain yang menjadi kendala adalah, apabila pemutaran dilakukan secara manual, kecepatan putaran kurang stabil. Ketidakstabilan putaran terjadi karena menggunakan tenaga manusia (bukan mesin) dan akibat faktor kelelahan pekerja. Ketidakstabilan putaran akan berdampak pada kualitas es krim, yaitu campuran kurang homogen atau tidak merata, serta waktu pembekuan yang tidak bersamaan. Dari sisi kesehatan juga kurang terjamin, karena ada kemungkinan keringat pekerja dan abu rokok yang jatuh ke dalam adonan es krim.

Permasalahan yang dihadapi mitra sekarang ini adalah masalah produksi yang kurang efisien, pengelolaan/manajemen usaha, perijinan, dan pemberian label. Hal ini yang membuat mitra sulit untuk berkembang dan sulit untuk mendapatkan bantuan kredit perbankan walaupun sebenarnya usaha yang mitra lakukan layak untuk dibiayai tetapi karena persyaratan administrasi yang tidak dapat mitra lengkapi, misalnya SIUP/TDP, NPWP, laporan keuangan dan lain-lain, maka permohonan kredit perbankan sulit untuk terealisasikan. Namaun demikian semangat dan kreativitas merupakan modal utama bagi kelompok usaha sejahtera bersama tersebut.

Secara umum, komposisi bahan-bahan pembuat es krim adalah: $10 \quad-16 \%$ lemak susu (milkfat), 9-12\% padatan susu bukan lemak (milk solids-non-fat, MSNF), $12-16 \%$ pemanis, 0,2-0,5\% penstabil (stabilizer) dan pengemulsi (emulsifier), dan 55-64\% air. Berdasarkan komposisinya, es krim terbagi menjadi 4 (empat) kategori, yaitu kategori ekonomi (economy brand), kategori standar (standard brand), kategori premium (premium brand), dan kategori super premium (super premium brand) (Person, 1980).

Es krim merupakan jenis makanan semi padat yang disukai oleh segala lapisan masyarakat, baik tua, muda, apalagi anak-anak. Dalam setiap acara pesta, misalnya pesta pernikahan, khitanan, ulang tahun, dan 
acara lainnya, menu es krim hampir selalu ada. Hidangan makanan/minuman tersebut umumnya dilayani oleh usaha catering yang banyak terdapat di kota, bahkan di desa. Selain dibuat oleh usaha catering, es krim juga banyak dibuat oleh home industri atau industri kecil yang khusus memproduksi es krim untuk dijual langsung ke konsumen dengan cara menetap maupun dijajakan keliling oleh para penjaja/pedagang.

Berdasarkan definisi yang dimuat dalam Standar Nasional Indonesia (SNI), es krim adalah jenis makanan semi padat yang dibuat dengan cara pembekuan es krim atau dari campuran susu, lemak hewan atau nabati, gula, dengan atau tanpa bahan makanan lain dan bahan makanan yang diijinkan (Dewan Standar Nasional-DSN, 1993: 1).

\section{Mesin Pembuat Es Krim}

Untuk membuat satu tabung (termos) dengan volume sekitar 10liter dibutuhkan bahan-bahan antara lain: kelapa 7 buah, gula pasir 2,5 kg, susu kental manis 1 kaleng, tepung hongkwe 1,5 kg, air masak, CMC (penghalus es krim), garam, vanili, dan perasa (esence) sesuai selera, misalnya rasa strawberi, coklat, duren, nangka, dsb. Setelah semua bahan disiapkan dan diolah, misalnya kelapa diparut untuk diambil santannya, dan dibuat adonan untuk dimasukkan ke dalam termos.

Adonan yang berupa cairan tersebut harus dibekukan. Caranya adalah dengan memasukkan termos ke dalam wadah atau otak yang berisi campuran es batu yang telah dihancurkan dan garam dapur. Langkah selanjutnya adalah memutar tabung tersebut selama kurang lebih 1,5-2 jam (apabila dikerjakan secara manual). Pada prinsipnya, proses ini adalah merupakan perubahan fisika, yaitu dari cair menjadi padat. Cairan dalam tabung dibekukan dengan media es batu, sedangkan garam berfungsi untuk mempercepat proses pendinginan/pembekuan.

Sebagai sumber tenaga penggerak putaran tabung (termos) terdapat beberapa pilihan, yaitu manual, semi mekanis, dan mekanis penuh atau dengan bantuan motor listrik. Dalam rancangan program IbM ini dipilih sumber tenaga motor bensin dengan pertimbangan bahwa motor bensin mudah didapat oleh pihak pengguna, diperlukan daya yang relatif tidak besar $( \pm 360$ Watt $)$, serta mudah dalam perawatannya.

Putaran motor umumnya 1400 RPM, sehingga putaran ini perlu direduksi (diturunkan) sampai sekitar 70 RPM, sesuai dengan putaran yang dilakukan secara manual. Karena penurunan putaran yang banyak, dalam rancangan ini dipakai alat reducer (gear box) dengan rasio 1:20. Untuk memindah putaran poros pemutar (dari gear box) ke poros pemutar es krim, terdapat tiga pilihan transmisi, yaitu sabuk, transmisi rantai, dan kabel atau tali. Dari beberapa pilihan tersebut, sabuk V lebih tepat digunakan karena lebih mudah penanganannya dan harganya murah (Sularso, 2002: 163).

Setelah mesin pemutar es krim dibuat dandapat berfungsi dengan baik, perlu diukur sejauhmana tingkat produktivitasnya. Untuk mengukur apakah dengan teknologi baru nanti produktivitas dapat meningkat, dapat digunakan formula pengukuran produktivitas $(\mathrm{P})=\mathrm{O} / \mathrm{I}$, dimana $\mathrm{O}=$ Output, dan $\mathrm{I}=$ Input (Syarif, 1991: 6). Ukuran output dapat dinyatakan dalam beberapa bentuk, antara lain: jumlah satuan fisik, misalnya dalam ukuran berat, volume, nilai rupiah, dan jumlah laba. Sedangkan ukuran input dapat dinyatakan dalam bentuk jumlah waktu, jumlah tenaga kerja, jumlah jam-orang, jumlah jam-mesin, dan lain-lain.

\section{METODE PELAKSANAAN}

Berdasarkan permasalahan yang telah di kemukakan, maka dalam kegiatan $\mathrm{I}_{\mathrm{b}} \mathrm{M}$ ini metode pendekatan yang digunakan adalah metode pendidikan, pelatihan pengelolaan dan manajemen usaha serta metode pendampingan untuk perbaikan proses produksi. Metode pelaksanaan yang ditawarkan untuk solusi dari permasalahan mitra dapat digambarkan seebagai berikut:

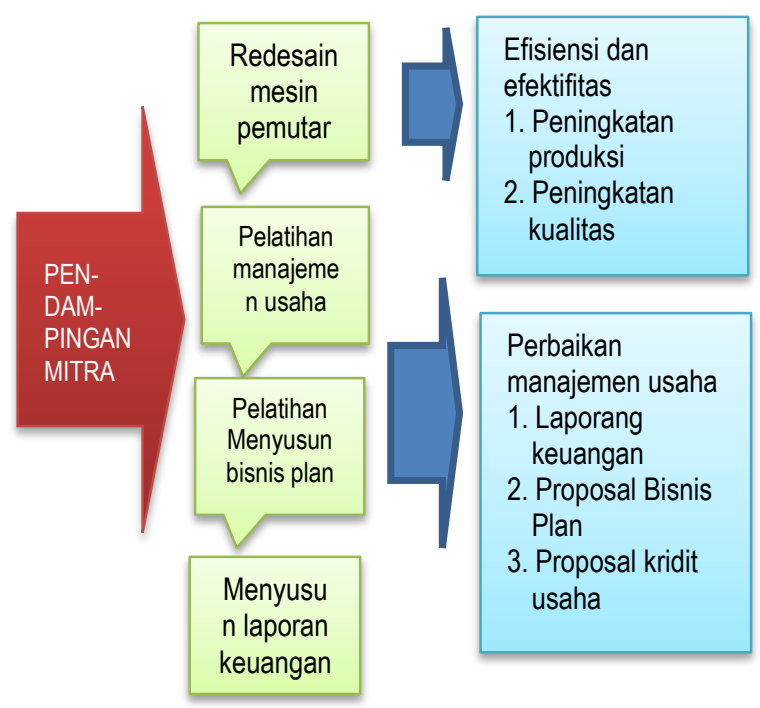

Gambar 1. Prosedur kerja

\section{HASIL DAN PEMBAHASAN}

Sasaran kegiatan ini adalah usaha pembuatan es krim yang dimiliki oleh Bp. Tukidi Alamat usaha adalah di Gang Parluhutan Jl. Perjuangan Medan. Jumlah karyawan industri kecil Bp. Tukidi pada saat ini berjumlah 8 orang. Hampir semua pekerja berasal dari kampung halaman Bp. Tukidi, yaitu dari Klaten Jawa Tengah. Pekerja yang semuanya laki-laki ini berumur antara 35-55 tahun. Tingkat pendidikan pekerja rata-rata SD dan SMP. Apabila semua pekerja masuk, maka tiap hari akan diproduksi 8 - 14 tabung es krim yang langsung dipasarkan hari itu juga (keliling).

Apabila di tambah dengan pesanan yang umumnya pada hari Sabtu-Minggu, maka omzet usaha lebih besar lagi. Dalam hal manajemen usaha, usaha es krim Bp. Tukidi masih bersifat tradisional. Hal ini dapat diketahui dari belum adanya 
pembukuan yang baik, tidak adanya merk tertentu yang dipakai, kemasan/wadah es krim yang sederhana, serta tidak ada promosi khusus untuk memperkenalkan produk kepada konsumen.

Seperti telah diuraikan dalam analisis situasi, kendala utama yang dihadapi selama ini adalah masalah produksi, Berdasarkan masukan pihak industri mitra, dalam tahap awal dibuat gambar rancangan mesin pemutar es krim dengan kapasitas dua tabung (termos) sekali proses. Sebelum dikerjakan, gambar ini dikonsultasikan lagi kepada pihak pengguna, yaitu pemilik dan pekerja yang terlibat dalam proses pembuatan es krim. Tahap ini bertujuan untuk mendapatkan saran dan masukan, sehingga mesin yang dibuat nanti benar-benar sesuai dengan yang diharapkan pengguna.

Langkah berikutnya adalah membuat gambar detail, berikut seluruh komponen yang dibutuhkan, dimensi/ukuran, serta bahan-bahan yang dibutuhkan. Tahap pembuatan dilaksanakan di bengkel kerja (work shop) Jurusan Teknik Mesin, Fakultas Teknik Universitas Negeri Medan dengan melibatkan beberapa teknisi dan pekerja. Saat ini masih dalam proses pengerjaan. Direncanakan sebelum diterapkan di industri mitra, mesin yang dibuat harus betul-betul sesuai dengan fungsi dan tujuan utama program ini. Uji coba mesin dilakukan di Laboratorium untuk menyempurnakan konstruksi, teknis operasional, serta tingkat produktivitas dan kualitas hasil seperti yang diharapkan.

Tim pelaksanan program IbM telah berhasil meredesain mesin pemutar es krim dengan desain dan kostruksi seperti gambar di bawah:

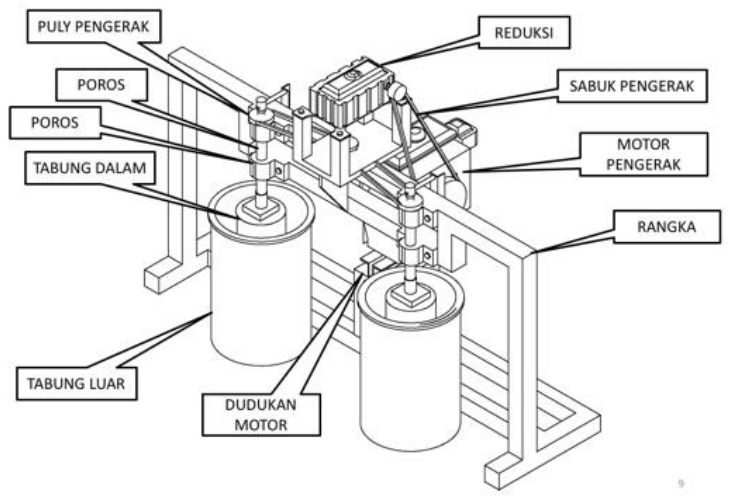

Gambar 2 Desain Mesin Pemutar Es Krim

Spesifikasi teknis mesin adalah sebagai berikut:

Dimensi keseluruhan $\quad: \mathrm{p} \times 1 \times \mathrm{t}=90 \mathrm{x}$

$90 \times 120 \mathrm{~cm}$

Ukuran tabung es krim

: Ø $25 \mathrm{~cm} \times 50 \mathrm{~cm}$

Jumlah tabung

Sumber tenaga

Reducer (Gear Box)

: 2 buah

: motor bensin $5 \mathrm{HP}$

Kecepatan putaran : 60-120 RPM

Kapasitas tabung : 2 × 20 liter $=$

40 liter

Lama produksi : 30 menit

Untuk mengetahui produktivitas mesin, dilakukan uji coba pembuatan es krim dengan melibatkan pengusaha es krim sebagai mitra kegiatan. Untuk membuat es krim (1 tabung), dibutuhkan bahan-bahan sebagai berikut:

1. Kelapa parut seharga Rp 40.000,- $( \pm 3 \mathrm{~kg})$

2. Susu kental manis 3 kaleng

3. Tepung maezena $250 \mathrm{gr}$

4. Gula pasir $4 \mathrm{~kg}$

5. Perasa (buah duren atau coklat)

6. Garam dapur \pm 3 cendok makan

7. Air matang: \pm 10 liter

8. Es balok: 2 balok

9. Garam grosok $\pm 7 \mathrm{~kg}$.

\section{Cara membuat:}

Pembuatan Adonan Es Krim:

1. Kelapa parut dibuat santan dengan menggunakan air matang \pm 10 liter.

2. Tepung maezena dibuat adonan dengan air santan $\pm 1 / 2$ liter.

3. Gula pasir dicairkan dengan air panas $\pm 1,5$ liter

4. Campurkan susu kaleng ke dalam santan dan ditambahkan sari buah (bila perlu) dan ditambahkan garam dapur.

5. Campurkan adonan maezena + gula cair ke dalam adonan air santan + susu.

6. Masukkan ke dalam tabung es krim yang sudah terpasang di mesin.

\section{Proses Pemutaran:}

1. Siapkan mesin pemutar dan sambungkan kabel ke sumber listrik.

2. Hancurkan es balok menjadi ukuran $3-5 \mathrm{~cm}$.

3. Masukkan hancuran es ke dalam sekeliling tabung hingga penuh sambil ditambahkan garam grosok.

4. Mesin siap diputar dengan menekan tomb "ON"

5. Selama mesin berputar, tabung dalam kondisi ditutup dan dapat dibuka sewaktu- waktu guna meratakan adonan atau memeriksa hasil es krim.

6. Apabila es krim sudah jadi sesuai dengan yang diinginkan, matikan mesin (tekan tombol "OFF") dan tabung dapat dipindah atau tetap dibiarkan di dalam mesin.

Berdasarkan uji coba yang telah dilakukan, es krim jadi dalam waktu \pm 30 menit ( $1 / 2$ jam). Waktu ini lebih singkat dibandingkan dengan waktu yang digunakan apabila dilakukan pemutaran dengan cara manual (dengan tangan). Hal ini terjadi karena kecepatan putaran tabung relatif lebih stabil dibandingkan dengan kecepatan putaran apabila diputar dengan tangan, yaitu sekitar 100 putaran per menit (RPM). Untuk membuat putaran tabung dalam mesin pemutar menjadi 100 RPM, dilakukan dengan memilih rasio putaran gigi reducer (gear box) yaitu 1:20. Kecepatan putaran motor bensin 2400 RPM, sehingga ouput putaran reducer menjadi 2400/20 $=120$ RPM. Diameter pulley reducer 6" dan pulley poros tabung 7", sehingga kecepatan putaran tabung $=6 / 7 \mathrm{x}$ $120=102$ RPM.

Satu unit mesin pemutar mampu memuat 2 tabung, sehingga dalam waktu 30 menit mampu 
dihasilkan 2 tabung es krim, atau 2 kali lipat dari produktivitas semula (cara manual).

Kualitas hasil es krim yang dibuat dengan mesin pemutar mempunyai kualitas yang sama baik dengan yang dihasilkan apabila dibuat secara manual. Hal ini bisa dilihat berdasarkan "rasa, tekstur, kelembutan, dan penampilan es krim. Bahkan mesin ini lebih higienis karena pemutaran dilakukan dengan mesin sehingga terhindar dari bau rokok maupun keringat pekerja/pemutar. Dari sisi produktivitas, kelebihan mesin ini adalah mampu meningkatkan kapasitas produksi hingga 2 kali lipat (200\%) karena sekali proses (30 menit) mampu dihasilkan 2 tabung es krim. Kelebihan lain adalah dibutuhkaan sedikit tenaga karena tabung berputar secara otomatis, sehingga mesin ini efektif dan efisien.

Walaupun mesin ini membutuhkan tambahan biaya bensin, pengusaha es krim masih tetap untung karena tidak perlu mengeluarkan upah pekerja/buruh tambahan. Waktu dan tenaga yang sebelumnya digunakan untuk memutar tabung dapat digunakan untuk mempersiapkan pekerjaan lain yang lebih bermanfaat.

Sebagai gambaran, apabila mendapat order/pesanan es krim dalam suatu acara (pesta perkawinan, rapat, dll) misalnya perlu dibuat 2 tabung es krim, apabila dikerjakan secara manual akan dibutuhkan 2 tenaga pemutar. Atau jika diputar oleh 2 orang akan dibutuhkan waktu lama (sekitar 3 jam). Namun dengan penerapan mesin pemutar ini cukup dikerjakan 1 orang dalam waktu relatif singkat (30 menit). Dengan demikian penerapan mesin pemutar es krim ini mempunyai nilai tambah ekonomi cukup tinggi.

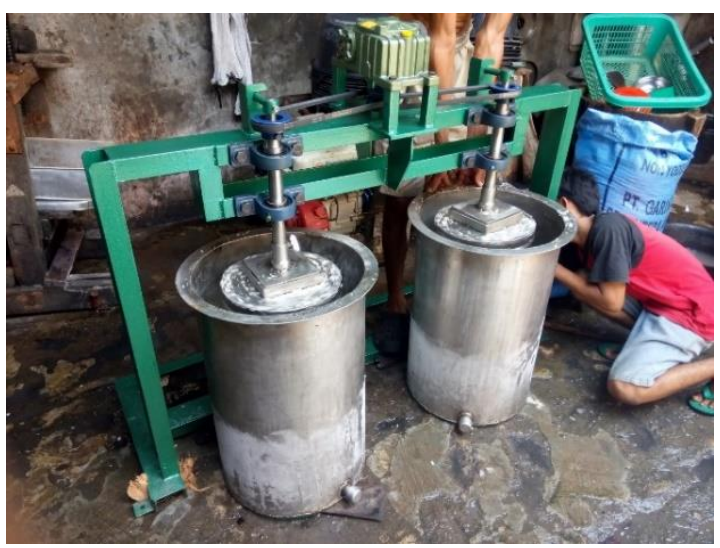

Gambar 3. Uji Coba Pembuatan Es Krim dengan Mesin Pemutar

\section{Perbaikan Manajemen Usaha}

Kebanyakan entrepreneur lebih tertarik pada ide-ide bisnis mereka dan menganggap manajemen keuangan adalah hal yang akan berjalan dengan sendirinya. Mereka berpikir jika bisnis bagus, keuangan juga akan sama bagusnya. Jika usaha untung, maka uang akan mengalir begitu saja.
Anggapan tersebut ada benarnya, namun dapat menyesatkan. Memang benar, sumber kas usaha adalah penjualan dan keuntungan. Namun bisnis tidak sekedar bagaimana menghasilkan uang, melainkan juga bagaimana membelanjakan dan mengendalikannya.

Manajemen keuangan bukan sekedar bagaimana memanajemen uang kas. Tapi lebih dari itu, manajemen keuangan adalah bagaimana anda mengelola kekayaan untuk menghasilkan keuntungan dan memanfaatkan sumber-sumber modal untuk membiayai usaha. Meski sederhana, pengusaha kecil dan menengah pun perlu menerapkan prinsip-prinsip manajemen keuangan. Beberapa dasar manajemen keuangan yang disampaikan kepada mitra anatara lain: (1) Memisahkan uang pribadi dan usaha. (2) Mencanakan penggunaan uang. (3) Mebuat buku catatan keuangan. (4) Menghitung keuntungan dengan benar. (5) Memutar arus kas lebih cepat. (6) Mengawasi harta, hutang dan modal. (7) Menyisihkan keuntungan untuk pengembangan usaha. dan (8) Teknik penyusunan Akuntansi

\section{KESIMPULAN}

Berdasarkan uraian sebelumnya, program vucer ini dapat terlaksana dengan baik, dengan hasil sebagai berikut:

1. Mesin pemutar es krim memiliki efisiensi dua kali lipat dibanding sebelumnya.

2. Mesin pemutar es krim mudah mengoperasikan

3. Mesin pemutar es krim sangat higihenes mitra sangat puas menerima mesin es krim

4. Mitra usaha memiliki buku laporan keuangan (buku kas, neraca rugi lapa, perhitungan keuntungan)

5. Mitra usaha dapat membuat proposal kridit usaha untuk mengembangkan usahanya

6. Mitra usaha siap untuk mengurus perijinan usaha dan membuat merek serta lebel dari balai POM dan MUI

7. Secara unit $\mathrm{kg} / \mathrm{satuan}$ waktu, massa adonan $20 \mathrm{~kg}$ yang lebih efektif karena besar unit ini adalah: $20 \mathrm{~kg} / 90$ menit $=2 / 9 \mathrm{~kg} /$ menit.

8. Rekomendasi yang dianjurkan penggunaan alat bantu produksi ini antara lain : sebelum memasukkan adonan ke tabung pemutar lebih baik pencampuran adonan ini menggunakan pencampur air yang dingin dan diaduk dengan mixer, agar memperoleh produk es krim yang baik, dan gunakan massa adoman $20 \mathrm{~kg}$, es batu48 kg (satu blok) dan garam curah $10 \mathrm{~kg}$.

\section{UCAPAN TERIMA KASIH}

Penulis mengucapkan terima kasih kepada Direktorat Jendral Perguruan Tinggi-Kementrian Riset dan Teknologi Pendidikan Tinggi (RISTEKDIKTI) dan Universitas Negeri Medan atas dukungan finansial dalam mendukung Ipteks bagi Masyarakat. 
IbM diibiayai berdasarkan Surat Perjanjian Pelaksanaan Kegiatan (SP2K) Nomor: 045/UN33.9/PM/2015 Tanggal 20 Maret 2015

\section{DAFTAR PUSTAKA}

Andrew Suyoto 2013 Laba Manis dari Bisnis Es

Putar http://www.Bisnisukm.com. (diakses 15 Maret 2014)

Dewan Standardisasi Nasional (DSN). 1993. Standar Nasional Indonesia (SNI). Handbook of Air Conditioning System Design. New York: McGraw-Hill Book Company

Sularso dan Kiyokatsu Suga. 2002. Dasar Perencanaan dan Pemilihan Elemen Mesin Jakarta: PT. Pradnya Paramita

Syarif, Rusli. 1991. Produktivitas. Bandung: Angkasa

Fuad,M.dkk. 2000. Pengantar Bisnis. Jakarta : Gramedia Monografi Kecamatan Pantai Labu.2012.

http://www.mandaeskrim.com Modal kecil, Untuk Besar, lezat, Sehat Laku Keras, (diakses 1 Maret 2014)

http://www.kursustristar.com/cara membuat-es-krimputer (diakses 15 Maret 2014)

http://www.informesin.com/peluang-bisnis-es-krimpeter Info Mesin - Pusat Mesin Indonesia (diakses 20 Maret 2014)

Sumodiningrat, 1999. Kemiskinan : Teori, Fakta dan Kebijakan. IMPAC. Jakarta. 